\title{
Growth and Yield Sensitivity of Four Vegetable Crops to Soil Compaction
}

\author{
David W. Wolfe', Daniel T. Topoleski, Norman A. Gundersheim, and Betsy A. Ingall \\ Department of Fruit and Vegetable Science, Cornell University, Ithaca, NY 14853
}

Additional index words. cabbage, Brassica oleracea, cucumber, Cucumis sativus, snap beans, Phaseolus vulgaris, sweet corn, Zea mays, soil strength, soil density, mechanical impedance, hardpan, root growth, leaf expansion, $\mathrm{CO}_{2}$ assimilation

\begin{abstract}
A 3-year field study conducted on an Eel silt loam soil (Aquic Udifluvent) compared cabbage (Brussica oleracea L. capitata group), cucumber (Cucumis sativus L.), snap bean (Phaseolus vulgaris L.), and sweet corn (Zea mays L.) for their growth and yield response to an artificially compacted soil layer beginning at about the 10-cm depth. Slower growing cabbage seedlings in compacted plots were more subject to flea beetle damage than the uncompacted controls. Prolonged flooding after heavy rainfall events in compacted areas had a more adverse effect on cabbage and snap bean than on cucumber or sweet corn. Sweet corn showed almost no growth reduction in one of the three years (1993) when relatively high fertilizer rates were applied and leaf nitrogen deficiencies in compacted plots were prevented. Maturity of cabbage, snap bean, and cucumber was delayed, and the average reduction in total marketable yield in (direct-seeded) compacted plots was $73 \%, 49 \%, 41 \%$, and $34 \%$ for cabbage, snap bean, cucumber and sweet corn, respectively. Yield reduction in transplanted cabbage (evaluated in 1993 only) was $29 \%$. In a controlled environment greenhouse experiment using the same soil type and similar compaction treatment as the field study, compaction caused a reduction in total biomass production of $30 \%$ and $14 \%$ in snap bean and cabbage, respectively, while cucumber and sweet corn showed no significant response. The growth reductions of snap bean and cabbage in the greenhouse could not be attributed to compaction effects on soil water status, leaf turgor, nutrient deficiency, or net $\mathrm{CO}$, assimilation rate of individual leaves. Root growth of sweet corn was least restricted by the compacted soil layer. The contrast between our field and greenhouse results indicates that the magnitude of yield response to compaction in the field was often associated with species sensitivity to secondary effects of compaction, such as prolonged flooding after rainfall events, reduced nutrient availability or uptake, and prolonged or more severe pest pressure.
\end{abstract}

The most common cause of soil compaction on farms is vehicle traffic, particularly the use of heavy equipment with poor weight distribution on wet soils (Hakansson et al., 1988). Compaction is a common problem in vegetable production systems because farm operations often must be conducted within narrow time windows that do not allow for adequate soil drying before entering the field.

Root growth of most species is highly sensitive to compaction and becomes very slow or completely ceases when penetrometer resistances begin to exceed $2.0 \mathrm{MPa}$ (review: Unger and Kaspar, 1994). Hardpans at shallow depth with penetrometer resistances well above $2.0 \mathrm{MPa}$ are common in many agricultural fields (van Es and Hill, 1995). Restricted root penetration into compacted soil layers can be due to insufficient root turgor pressure to overcome the mechanical impedance of the soil (Veen, 1982), or, when soil water content is high, may be associated with insufficient oxygen availability for root respiration and continued growth (Lemon and Wiegand, 1962).

The restricted root distribution in compacted soils can lead to reductions in shoot growth and yield by limiting water and nutrient uptake (Hakansson et al., 1988). Van Es and Hill (1995) suggested that reduced water availability during dry periods may be the most significant yield-limiting consequence of soil compaction in the Northeastern U.S. Conversely, prolonged flooded periods after heavy rainfall events on compacted soils adversely affect root metabolism and growth, increase the likelihood and severity of root diseases (Allmaras et al., 1988), and increase the activity of anaerobic denitrifying bacteria, thus reducing nitrogen $(\mathrm{N})$ avail-

Received for publication 16 Mar. 1995. Accepted for publication 23 May 1995. This work was supported by U.S. Dept. of Agr. Hatch Grant NYC 161422 (DWW). We thank S. McKay for assistance in preparation of the field plots and J. Melkonian for assistance with leaf water potential and photosynthesis measurements. The cost of publishing this paper was defrayed in part by the payment of page charges. Under postal regulations, this paper therefore must be hereby marked advertisement solely to indicate this fact.

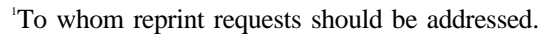

ability (Lowery and Schuler, 1991).

Controlled environment experiments with wheat (Masle and Passioura, 1987; Masle and Farquhar, 1988) and a field study with sunflower (Andrade et al., 1993) documented that leaf expansion and growth of young seedlings are significantly reduced in plants grown on compacted soils even when water, oxygen, and nutrients are not limiting factors. Measurements of the net $\mathrm{CO}$, assimilation rates $\left(\mathrm{A}_{\mathrm{CO} 2}\right)$ of individual leaves in these studies also indicated that growth was not limited by carbohydrate supply. These authors suggested that mechanical impedance of compacted soils may cause production of a hormonal signal in the roots which controls shoot response. Additional research examining a broader range of plant species will be necessary to verify these findings. Increases in levels of abscisic acid (Hartung et al., 1994), ethylene (Kays et al., 1974), and 1H-indole-3-acetic acid (Lachno et al., 1982) have been measured in the roots of plants growing on compacted soils, but results have not been consistent, and no consensus has been reached on the importance or mechanism of hormonal control of plant response to compaction.

The quantification of the impact of soil compaction on crop yield has focused primarily on agronomic species. Although results vary depending on the particular species and environmental conditions, yield reductions of $20 \%-50 \%$ or more have frequently been reported (e.g. Brereton et al., 1986; Hakansson et al., 1988; Henderson, 1991). An observational trial comparing the yield response of nine vegetable crops to compaction (Orzolek, 199 1) found an average yield reduction of $56 \%$, and a range from $13 \%$ (watermelon) to $75 \%$ (snap bean). Cabbage, cucumber and sweet corn showed yieldreductions of $65 \%, 66 \%$, and $55 \%$, respectively. Additional replicated experiments will be required to determine more conclusively the relative sensitivity of various vegetable crop species to compaction.

The objectives of this 3-year replicated study were to 1) compare the relative growth and yield sensitivity of four vegetable 


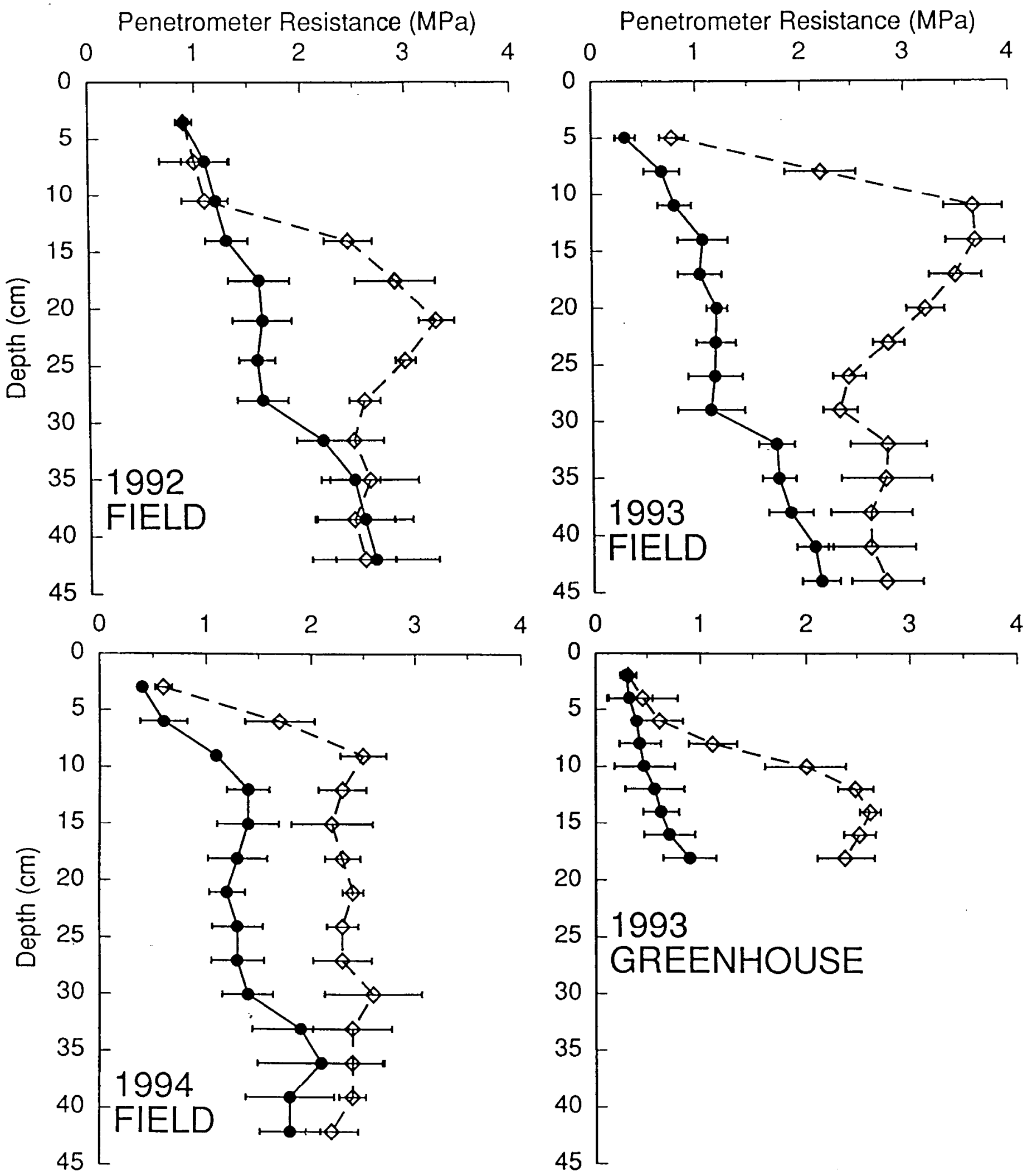

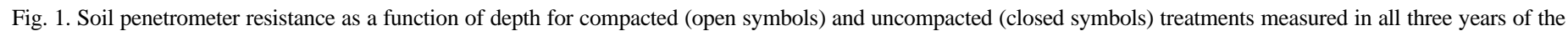
field study, and in the greenhouse experiment as indicated. Each value is the mean of four to eight replications. Horizontal bars indicate \pm SE values.

crops-cabbage, cucumber, snap bean, and sweet corn-to soil compaction in the field; 2) contrast these results to those obtained under controlled greenhouse conditions where secondary compac- tion effects on soil and leaf water status and nutrient availability could be minimized; and 3) compare the four species for their root penetration into compacted soil layers. 


\section{Materials and Methods}

\section{Soil compaction treatments}

Field. Three field studies were conducted between 1992 and 1994 at the Homer C. Thompson Vegetable Research Farm in Freeville, N.Y., on an Eel silt loam soil (fine-loamy, mixed, nonacid mesic Aquic Udifluvent). Compaction main plot strips, 3 $\mathrm{m}$ wide and $15 \mathrm{~m}$ long, were prepared in 1992 and 1993 by excavating the top $10 \mathrm{~cm}$ of soil, sprinkler-irrigating the area with about $2 \mathrm{~cm}$ of water, and $48 \mathrm{~h}$ later driving over the treatment area with a $3000 \mathrm{~kg}$ power roller a minimum of 10 times. The excavated soil was then replaced over the compacted layer. The same procedure was used in 1994, except that no soil was excavated prior to compaction, and a tractor weighing about $6200 \mathrm{~kg}$ was used to create the compacted layer. The uncompacted, control, main plots consisted of undisturbed strips of the same dimensions as the compacted strips. After preparation of the main plots, broadcast fertilizer was applied, and the entire field was leveled and springtooth harrowed to a depth of about $15 \mathrm{~cm}$.

Soil compaction as a function of depth was measured several times in each compacted and uncompacted main plot, when soil water potentials were between -0.01 and $-0.03 \mathrm{MPa}$, with a soil penetrometer (Bush SP-1000; Midlothian, Scotland, in 1992; Eijkelkamp 6.02; Giesbeek, The Netherlands, in 1993 and 1994). The compacted zone (defined here as >2.0 MPa penetrometer resistance) was at about the 15 to $30 \mathrm{~cm}$ depth in 1992, 10 to $40 \mathrm{~cm}$ depth in 1993, and 7 to $30 \mathrm{~cm}$ depth in 1994 (Fig. 1). The compacted layer did not significantly deteriorate during the course of the growing season in any of the experiments.

Greenhouse. The same Eel silt loam soil was used in the 1993 greenhouse experiment. The soil was collected from the field, dried, and passed through a $5 \mathrm{~mm}$ sieve. The pots were polyvinyl chloride (PVC) cylinders, with a $20 \mathrm{~cm}$ interior diameter, $1.3 \mathrm{~cm}$ wall thickness, and $23 \mathrm{~cm}$ length. A plywood board, $2 \mathrm{~cm}$ thick and $25 \times 25 \mathrm{~cm}$ square, served as a bottom for each cylinder. The primary purpose of the false bottom was to facilitate later removal of soil and roots. A lower compacted layer was created by adding soil in 2 to $3 \mathrm{~cm}$ increments up to a height of $10 \mathrm{~cm}$, pounding the soil with a steel ramming rod between each addition of soil. To prevent roots growing down the sides of the pot when they reached the compacted layer, $1.3 \mathrm{~cm}$ diameter Tygon tubing was glued with silicone sealant to the inner circumference of the pot at the top of the compacted layer. Soil was then added to create the upper 10$\mathrm{cm}$ uncompacted layer. Soil penetrometer resistance measured with the Eijkelkamp Penetrometer, at about $-0.02 \mathrm{MPa}$ soil water potential, verified that the procedure created a significant compacted layer in the compaction treatment at the $10-20 \mathrm{~cm}$ depth (Fig. 1).

\section{Experimental design and cultural practices}

Field. A split-plot factorial design was used in all three repetitions of the field experiment, with soil treatment (uncompacted or compacted as described above) as main plot, and vegetable crop as subplot. The four crops compared in all 3 years were cabbage ('Solid Blue 780'), cucumber ('Marketmore 76'), snap bean (Phaseolus vulgaris 'Bush Blue Lake 274'), and sweet corn ('Clockwork' in 1992, 'Calico Belle' in 1993 and 1994). There were four replications in 1992 and 1994, and three replications in 1993.

Preplant broadcast fertilizer application was $13 \mathrm{~kg} \mathrm{~N}, 6 \mathrm{~kg} \mathrm{P}$ and $11 \mathrm{~kg} \mathrm{~K} / \mathrm{ha}$ in 1992; $103 \mathrm{~kg} \mathrm{~N}, 45 \mathrm{~kg} \mathrm{P}$, and $84 \mathrm{~kg} \mathrm{~K} / \mathrm{ha}$ in 1993; and $108 \mathrm{~kg} \mathrm{~N} / \mathrm{ha}$ in 1994. A subsequent sidedress $\mathrm{N}$ application (as urea) was applied 4 to 5 weeks after seeding at a rate of $72 \mathrm{~kg} \mathrm{~N} /$ ha in 1992, $90 \mathrm{~kg} \mathrm{~N} / \mathrm{ha}$ in 1993 , and $45 \mathrm{~kg} \mathrm{~N} / \mathrm{ha}$ in 1994 . Thus, total $\mathrm{N}$ applied was relatively low in 1992 , high in 1993 , and moderate in 1994.

The four crops were direct field-seeded on 16 June in 1992, 15 June in 1993, and 1 July in 1994. The crops were seeded in rows perpendicular to the main plot strips, and thinned at about three weeks after seeding to desired in-row spacings of $30 \mathrm{~cm}$ for cabbage and cucumber, $5 \mathrm{~cm}$ for snap bean, and $23 \mathrm{~cm}$ for sweet corn. There were two rows, $3.0 \mathrm{~m}$ long, for each subplot of cabbage, cucumber and snap beans, and four rows in each sweet corn subplot. The between-row width was $0.9 \mathrm{~m}$ for cabbage, snap bean and sweet corn, and $1.8 \mathrm{~m}$ for cucumber. A fifth vegetable crop treatment-transplanted cabbage-was evaluated in 1993. The cabbage (same cv. used for direct field-seeding) was seeded into Speedling trays with a $5 \times 5 \times 7.5 \mathrm{~cm}$ cell size on 15 June and transplanted to the field on 13 July. Tensiometers (Irrometer, Riverside, Calif.) were installed at a depth of 15 to $20 \mathrm{~cm}$ (at least one in each compacted and uncompacted main plot) to monitor soil moisture level.

Weeds were controlled by hoeing. Endosulfan (Thiodan 3EC) applied at $0.8 \mathrm{~kg}$ a.i./ha with a backpack sprayer was used for flea beetle control (every 5 to 10 days if necessary) in the cabbage during the first several weeks after planting in all 3 years. No other significant insect or disease problems were evident.

Greenhouse. After preparing compacted and uncompacted 20 $\times 23 \mathrm{~cm}$ pots as described above, the soil water content was brought up to pot capacity by subirrigating them for several days in $3 \times 1.5$ $\mathrm{m}$ polyethylene-lined trays filled with water to a depth of about 4 $\mathrm{cm}$. The water was then drained from the trays, and the pots were covered and allowed to freely drain for $24 \mathrm{~h}$ before seeding (four seeds per pot) on 17 Sept. 1993 with the same four crops and cultivars used in the 1993 and 1994 field studies. Ten pots (replications) of each soil treatment (uncompacted and compacted at a $10 \mathrm{~cm}$ depth) and each crop were arranged in a completely randomized factorial design on the greenhouse bench and rerandomized every 2 to 3 days to minimize location effect. Previous experiments conducted in the same greenhouse setting indicated that block designs were not efficient because of multiple, unpredictable, and nonlinear environmental gradients. All pots were thinned to two plants on 26 Sept. Greenhouse settings maintained temperatures between $21 \mathrm{C}$ and $26 \mathrm{C}$ (day) and $15 \mathrm{C}$ to $20 \mathrm{C}$ (night), and daytime relative humidity between 55\% and $65 \%$. Supplemental metal halide overhead lighting maintained a minimum 14-h photoperiod throughout the experiment.

Soil water potential, measured by tensiometers at the 10 and 15 $\mathrm{cm}$ depth, and daily evapotranspiration, determined gravimetritally, were monitored in two pots from each crop/compaction treatment. This information was used to determine the amount of water applied on a daily basis to all pots in the experiment. Daily evapotranspiration losses were not replaced until soil water potentials declined to about $-0.01 \mathrm{MPa}$ (27 Sept.), and throughout the experiment pots were maintained at soil water potentials in the optimum range of -0.01 to $-0.03 \mathrm{MPa}$. Pots were fertilized every four days, beginning at thinning, with $125 \mathrm{ml}$ of a liquid fertilizer containing $\left(\mathrm{mg} \cdot \mathrm{liter}^{-1}\right): 450 \mathrm{~N}$ (53\% in nitrate form); $210 \mathrm{P}$; and $420 \mathrm{~K}$.

\section{Plant measurements}

Field. Leaf and petiole samples were collected from each sweet corn and snap bean plot for tissue analysis early in the growing season in 1992 (7 July) when visible symptoms of N deficiency were observed in some compacted plots. The samples were dried and analyzed at Cornell's Fruit and Vegetable Science Analytical 
Laboratory for total $\mathrm{N}$, using a modified micro-Kjeldahl technique (Bremner, 1965), and P, K, and other major elements, using a calibrated ICP atomic emission spectrophotometer after standard dry ash preparation. Leaf and petiole samples were collected for the same tissue analysis from all treatments on 5 Aug. in the 1993 experiment. No tissue analyses were conducted in 1994.

The threat of an early frost event in 1992 required that the experiment be terminated on 3 Sept. with a destructive harvest of the above-ground portion of plants from a $1.5 \mathrm{~m}$ section of one row from each subplot. Plants were counted, and fresh weight of leaves, stem and fruit measured. Cabbage and sweet corn plants had not reached maturity (no marketable yield) at this time.

In 1993 and 1994, a 2.0 m section of one row from each subplot was selected for marketable yield and biomass measurement. The harvest dates for cucumber and snap bean in 1993 were 16 Aug. through 8 Sept. (six repeat harvests). Sweet corn and cabbage were once-over harvested in 1993 on 8 Sept. (sweet corn), and 20 and 30 Sept. (uncompacted and compacted cabbage plots, respectively). Harvests in 1994 were 8 to 23 Sept. for cucumber and snap bean; 5 Oct. for sweet corn; and 20 Oct. for cabbage. At the final destructive harvests in 1993 and 1994, plant number was recorded, leaf, stem and fruit were weighed separately, and subsamples of each of these plant parts were dried at $70 \mathrm{C}$ for 3 to 4 days. Total dry weight/plant was estimated from the subsample dry weight/fresh weight ratios. The average of the dry weight/fresh weight ratios for leaf plus stem and fruit from 1993 and 1994 were used to estimate dry weight production in 1992 when only fresh weights were measured.

Greenhouse. The length of all leaves $>0.5 \mathrm{~cm}$ in length was measured with a ruler on a daily basis on four plants per treatment from 26 Sept. to 8 Oct. to determine leaf elongation rate (LER). On 3 Oct., the most recently fully expanded leaf (plus petiole) was removed from three plants of each treatment for tissue analysis of $\mathrm{N}, \mathrm{P}, \mathrm{K}$, and other major elements. Net $\mathrm{CO}_{2}$ assimilation rates $(\mathrm{A},,$,$) were measured in situ on 5$ Oct. (snap bean and sweet corn) and 11 Oct. (cabbage and cucumber) on the most recently fully expanded leaf, and the next higher leaf position, on five plants from each treatment with a portable, closed leaf gas exchange system (LI-6200; LI-COR, Lincoln, Neb.). All measurements were made near midday, and with photosynthetic photon flux density between 800 to $900 \mu \mathrm{mol} \cdot \mathrm{m}^{-2} \cdot \mathrm{s}^{-1}$. Other environmental conditions within the leaf chamber during the 20 to 30 -sec measurement period were: 25 to $28 \mathrm{C}$ leaf temperature; 340 to $370 \mu \mathrm{mol} \cdot \mathrm{m}^{-2} \cdot \mathrm{s}^{-1} \mathrm{CO}_{2}$ concentration, and 1.7 to $2.4 \mathrm{kPa}$ vapor-pressure deficit. A $1.5 \mathrm{~cm}$ leaf disk was removed from expanding leaves (one node above the most recently fully expanded leaf) of four plants of each treatment at midday on 4 Oct. for leaf water potential determination using a calibrated modified Peltier thermocouple psychrometer (Decagon Devices, Inc., Pullman, Wash.). Solute potential was measured after freezing $(-10 \mathrm{C}, 48 \mathrm{~h})$ and thawing the leaf sections. The leaf pressure (turgor) potential was calculated from the difference between total and solute potential.

The above-ground portion of one plant from five pots of each treatment was harvested on 5 Oct. (snap bean and sweet corn) and 6 Oct. (cabbage and cucumber). Leaf and stems were separately dried at 70C for $48 \mathrm{~h}$ and weighed. A final destructive harvest of five plants per treatment was made on 8 Oct. (snap bean and sweet corn), 12 Oct. (cucumber) and 13 Oct. (cabbage). Leaf and stem dry weight were determined as in the first harvest, and in addition, roots growing in the upper and lower 10-cm layers were separated, carefully washed from the soil, dried and weighed. Mean relative growth rate (RGR) was calculated as the difference in the log of the above-ground dry weights from the two harvests divided by the number of days between harvests.
Statistical analyses. Analysis of variance to determine soil and crop treatment main effects, and their interaction, were performed on field (split-plot factorial design) and greenhouse (completely randomized factorial design) data using statistical software (SuperANOVA; Abacus Concepts, Berkeley, Calif.). Additional $t$ tests were used to compare compacted vs. uncompacted treatments within individual crops.

\section{Results}

\section{Field experiments}

Averaging across the 3 years, the reduction in above-ground biomass associated with soil compaction treatment (Table 1) was greatest in cabbage (63\%) followed by snap bean (48\%), cucumber $(46 \%)$ and sweet corn (29\%). These differences between species in their growth sensitivity to compaction were reflected in a significant soil treatment $\mathrm{x}$ crop interaction in all 3 years. The average reduction in total marketable yield in (direct-seeded) compacted plots was $73 \%, 49 \%, 41 \%$, and $34 \%$ for cabbage, snap bean, cucumber, and sweet corn, respectively. In 1993, a transplanted cabbage treatment was included, and yield reductions associated with compaction were less for the transplanted cabbage (29\%) compared to direct-seeded cabbage (64\% reduction) in that year (Table 1).

Crop maturation rate and early yield of cabbage, cucumber and snap bean were affected by compaction, but this was not true for sweet corn. Averaging the 1993 and 1994 results, when cucumber and snap bean were repeat-harvested, the reduction in early yield was $38 \%$ for cucumber and $60 \%$ for snap beans (Table 1). Soil treatment main effect on early yield was not statistically significant in 1993 because of large variability in cucumber response. A t test comparison between snap bean compacted and uncompacted treatments in that year was highly significant $(P<0.01)$, but this was not true for cucumber. In 1994 the effect of compaction on early yield was statistically significant for both crops, although ANOVA soil treatment main effect was not significant $(\mathrm{P}=0.08)$ due to the significant interaction.

Year-to-year variation in response to compaction (Table 1) was in part due to yearly variation in precipitation patterns and more prolonged flooding in compacted plots after heavy rainfall events. In the first year, 1992, heavy rains during the last week of June (15 to 20 days after planting) led to a period of about 6 days of saturated soil (soil water potentials at the $15.0 \mathrm{~cm}$ depth near $0.00 \mathrm{MPa}$ ) in the compacted plots compared to about a 2-day period of saturation in the uncompacted plots. No flooding occurred in 1993, but late in the 1994 season (50 to 55 days after planting), heavy rains again created a more prolonged period of saturated soil in the compacted compared to uncompacted plots. Cabbage and snap beans in the compacted treatments were more visibly stunted (cessation of growth for several days to two weeks) by these short-term flooding events in 1992 and 1994 than cucumber or sweet corn. Biomass production of cabbage was reduced in compacted plots by more than $70 \%$ in the years when flooding occurred, compared to a $45 \%$ reduction in 1993. Snap beans showed a $60 \%$ total yield reduction in 1994 when late season flooding occurred, compared to a $41 \%$ reduction in 1993 when there was no flooding, and a $42 \%$ reduction in 1992 when flooding was in the early part of the season.

Variation in fertilizer applied also contributed to the year-toyear differences in crop (particularly sweet corn) response to compaction. In 1993, when fertilizer rates were relatively high, sweet corn showed essentially no reduction in biomass production and only a $6 \%$ reduction in yield on compacted soil (Table 1). Leaf tissue analyses indicated relatively high $\mathrm{N}, \mathrm{P}$, and $\mathrm{K}$ levels for 
Table 1. The effect of soil compaction under field conditions on above-ground dry weight (biomass), marketable fresh weight yield, and average fruit fresh weight. All crops were direct-seeded unless otherwise indicated.

\begin{tabular}{|c|c|c|c|c|c|c|c|c|c|}
\hline \multirow[b]{3}{*}{ Year } & \multirow[b]{3}{*}{ Crop } & \multirow{2}{*}{\multicolumn{2}{|c|}{$\begin{array}{c}\text { Total } \\
\text { above-ground } \\
\text { biomass (g/plant) }\end{array}$}} & \multicolumn{4}{|c|}{ Marketable yield (kg/ha) } & \multirow{2}{*}{\multicolumn{2}{|c|}{$\begin{array}{c}\text { Average wt } \\
\text { (kg/fruit, head) }\end{array}$}} \\
\hline & & & & \multicolumn{2}{|c|}{ Early $^{\mathrm{Z}}$} & \multicolumn{2}{|c|}{ Total } & & \\
\hline & & Control & Compact & Control & Compact & Control & Compact & Control & Compact \\
\hline \multirow[t]{4}{*}{1992} & Cabbage & 42.1 & 11.6 & $-\overline{--}$ & --- & $-y^{y}$ & --- & -- & $\begin{array}{c}-- \\
--\end{array}$ \\
\hline & Cucumber & 98.4 & 56.4 & --- & $\ldots$ & 15,200 & 11,133 & $\ldots$ & --- \\
\hline & Snap bean & 33.0 & 19.0 & --- & --- & 16,083 & 10,461 & --- & --- \\
\hline & Sweet corn & 93.4 & 57.2 & --- & --- & $\ldots y$ & --- & & \\
\hline \multicolumn{2}{|c|}{ Soil treatment (S) } & \multicolumn{2}{|c|}{$* * *$} & & & \multicolumn{2}{|c|}{ NS $(0.11)$} & & \\
\hline \multicolumn{2}{|c|}{ Crop (C) } & \multicolumn{2}{|c|}{$* * *$} & & & \multicolumn{2}{|c|}{ NS } & & \\
\hline \multicolumn{2}{|c|}{$\mathrm{S} \times \mathrm{C}$} & \multicolumn{2}{|c|}{$* *$} & & & \multicolumn{2}{|c|}{ NS } & & \\
\hline \multirow[t]{5}{*}{1993} & $\begin{array}{l}\text { Cabbage } \\
\text { Cabbage }\end{array}$ & 178.5 & 98.3 & --- & -- & 44,106 & 15,942 & 1.18 & 0.86 \\
\hline & (transplanted) & --- & --- & --- & --- & 32,112 & 22,780 & 0.99 & 0.83 \\
\hline & Cucumber & 301.3 & 168.2 & 10,934 & 7,431 & 61,755 & 34,820 & 0.31 & 0.29 \\
\hline & Snap bean & 35.5 & 21.0 & 11,091 & 4,464 & 23,758 & 11,462 & --- & $--\quad ;$ \\
\hline & Sweet corn & 125.1 & 124.7 & --- & --- & 10,642 & 9,980 & 0.25 & 0.26 \\
\hline \multicolumn{2}{|l|}{$S$} & \multicolumn{2}{|c|}{$*$} & \multicolumn{2}{|c|}{ NS } & \multicolumn{2}{|c|}{$*$} & \multicolumn{2}{|c|}{ NS $(0.15)$} \\
\hline \multicolumn{2}{|c|}{$\mathrm{C}$} & \multicolumn{2}{|c|}{$* * *$} & \multicolumn{2}{|c|}{ NS } & \multicolumn{2}{|c|}{$* * *$} & \multicolumn{2}{|c|}{$* * *$} \\
\hline \multicolumn{2}{|c|}{$\mathrm{S} \times \mathrm{C}$} & \multicolumn{2}{|c|}{$*$} & \multicolumn{2}{|c|}{ NS $(0.25)$} & \multicolumn{2}{|c|}{ * } & NS ( & $0.15)$ \\
\hline 1994 & Cabbage & 99.4 & 26.4 & $\ldots$ & --- & 16,206 & 2,811 & 0.45 & 0.10 \\
\hline & Cucumber & 75.8 & 36.3 & 439 & 250 & 19,308 & 9,085 & 0.31 & 0.28 \\
\hline & Snapbean & 20.4 & 8.1 & 11,382 & 4,522 & 14,211 & 5,441 & --- & --- \\
\hline & Sweet corn & 89.5 & 45.8 & -- & --- & 9,699 & 3,673 & 0.23 & 0.21 \\
\hline $\mathrm{S}$ & & & & & $(0.08)$ & & $* *$ & & $*$ \\
\hline $\mathrm{C}$ & & & & & $* * *$ & & $*$ & & $*$ \\
\hline$S>$ & & & & & $*$ & & $0.18)$ & & $* *$ \\
\hline
\end{tabular}

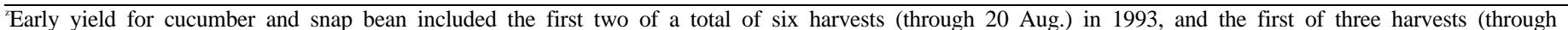
8 Sept.) in 1994. These crops were once-over harvested in 1992, as were cabbage and sweet corn in all 3 years.

Cabbage and sweet corn did not grow to maturity in 1992 due to early frost.

NS,***,***Nonsignificant or significant at $P<0.05,0.01$, and 0.001 , respectively.

sweet corn in that year, and no compaction effect on leaf nutrient status (Table 2). In contrast, in 1992 and 1994, when low to moderate fertilizer rates were used, sweet corn biomass production was reduced $40 \%$ to $50 \%$ in the compacted treatment (Table 1). Leaf tissue analyses in 1992 (not measured in 1994) indicated $\mathrm{N}$ in compacted plots was near the deficiency level for both sweet corn and snap bean (Table 2).

\section{Greenhouse experiment}

Leaf elongation rate of leaves emerging during the first week after planting was slightly lower in compacted pots for all species, but soil treatment main effect (averaged across all four species) was not statistically significant (Table 3). Snap bean was most sensitive, with a $20 \%$ slower rate of leaf expansion of compacted vs. uncompacted treatments, significant at $P<0.01$ (individual $t$

Table 2. Leaf and petiole tissue analyses for nitrogen, phosphorus, and potassium measured in 1992 and 1993 field experiments. Cabbage and cucumber were not measured in 1992.

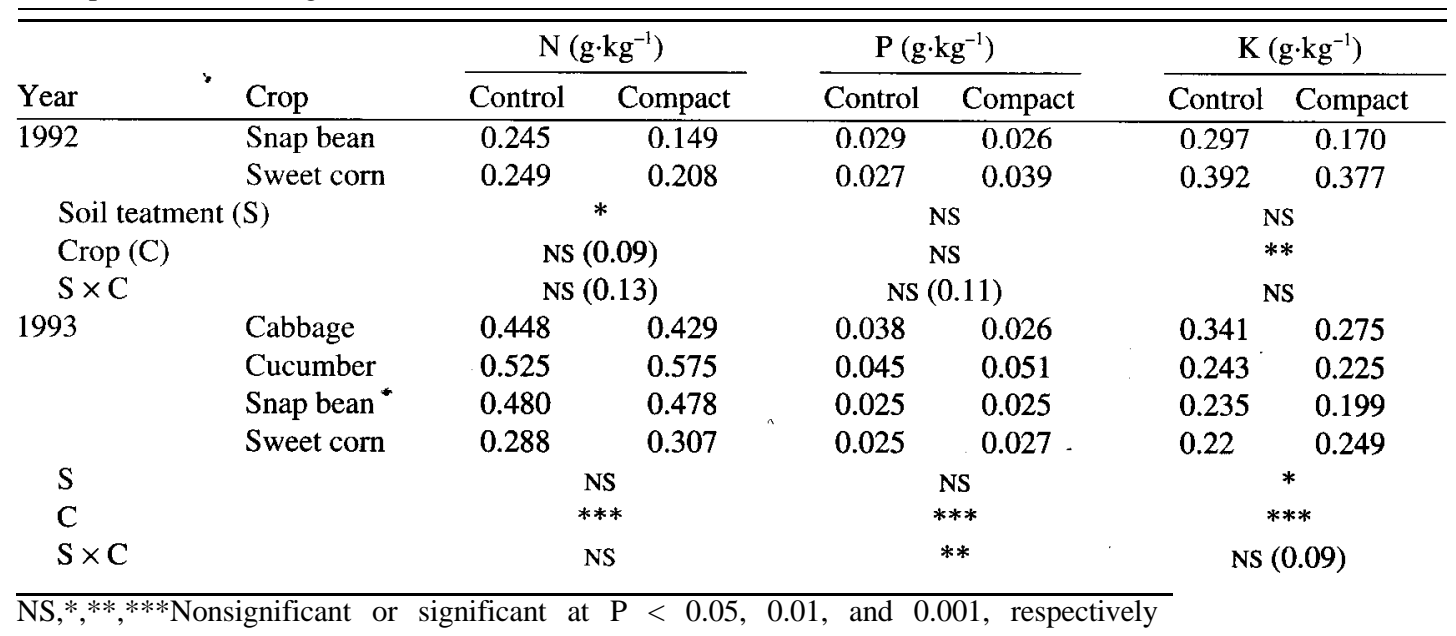


Table 3. Effect of soil compaction in the greenhouse experiment on leaf elongation rate (LER), mean relative growth rate (RGR), and final harvest total biomass, root : shoot ratio (dry weight basis), and percent roots in the lower 10$\mathrm{cm}$ zone (compacted layer of compacted treatments).

\begin{tabular}{|c|c|c|c|c|c|c|}
\hline Crop & Treatment & $\begin{array}{c}\mathrm{LER}^{z} \\
(\mathrm{~cm} / \text { day })\end{array}$ & $\begin{array}{c}\text { RGR } \\
\left(\mathrm{g} \cdot \mathrm{g}^{-1} \cdot \mathrm{day}^{-1}\right)\end{array}$ & $\begin{array}{l}\text { Total biomass } \\
\text { (g/plant) }\end{array}$ & Root: shoot & $\begin{array}{l}\text { Roots (\%) } \\
\text { lower zone }\end{array}$ \\
\hline \multirow[t]{2}{*}{ Cabbage } & Control & 0.70 & 0.30 & 6.57 & 0.18 & 34.6 \\
\hline & Compact & 0.72 & 0.32 & 5.64 & 0.13 & 16.2 \\
\hline \multirow[t]{2}{*}{ Cucumber } & Control & 0.73 & 0.20 & 8.36 & 0.27 & 41.6 \\
\hline & Compact & 0.68 & 0.22 & 8.26 & 0.21 & 9.2 \\
\hline \multirow[t]{2}{*}{ Snap bean } & Control & 1.68 & 0.29 & 6.63 & 0.18 & 64.2 \\
\hline & Compact & 1.34 & 0.20 & 4.65 & 0.12 & 14.8 \\
\hline \multirow[t]{2}{*}{ Sweet corn } & Control & 3.45 & 0.26 & 6.11 & 0.21 & 35.8 \\
\hline & Compact & 3.32 & 0.33 & 5.91 & 0.16 & 20.2 \\
\hline \multicolumn{2}{|c|}{ Soil treatment (S) } & NS $(0.06)$ & NS & $* *$ & $* * *$ & $* * *$ \\
\hline \multicolumn{2}{|c|}{ Crop (C) } & $* * *$ & $* * *$ & $* * *$ & $* * *$ & $*$ \\
\hline \multicolumn{2}{|l|}{$\mathrm{S} \times \mathrm{C}$} & NS $(0.26)$ & $* * *$ & NS $(0.10)$ & NS & ** \\
\hline
\end{tabular}

${ }^{2}$ Leaf elongation rate for leaf at node 2 (counting up from stem base) for cabbage, cucumber, and snap bean, and at node 3 for sweet corn.

$\mathrm{NS}, * * *, * * *$ Nonsignificant or Significant at $\mathrm{P}<0.05,0.01$, and 0.001 , respectively

test). Mean RGR was about $30 \%$ lower in compacted compared to uncompacted snap bean treatments, but the other three species showed no RGR reduction, and the ANOVA soil treatment $\mathrm{x}$ crop interaction was highly significant. Total plant biomass at the final destructive harvest (about four weeks after planting) was most reduced by compaction in snap bean $(30 \%$ lower in compacted compared to uncompacted treatment), followed by cabbage with about a $14 \%$ reduction (Table 3 ). There was no compaction effect on total biomass of sweet corn and cucumber.

Root growth of all four species was significantly affected by compaction. The root : shoot ratio in the compacted treatment was reduced by $33 \%, 21 \%, 23 \%$, and $22 \%$ for snap bean, cabbage, cucumber, and sweet corn, respectively (Table 3). The proportion of roots which penetrated into the lower $10 \mathrm{~cm}$ of the pots (the compacted layer in compaction treatments) was reduced in compacted pots for all species, but sweet corn showed the least difference between the control and compaction treatment (Table 3).

The growth reductions in snap bean and cabbage could not be attributed to a compaction effect on $\mathrm{A}_{\mathrm{CO} 2}$ of individual leaves (Table 4). Plant nutrition was also not likely a factor. Leaf N, P, and $\mathrm{K}$ concentrations were relatively high for all crops regardless of soil treatment (Table 4), and no visual deficiency symptoms were observed. However, leaf nutrient values were slightly lower in compacted vs. uncompacted cabbage plants. Total leaf water potential, and solute and calculated pressure potentials were not significantly different between compacted and uncompacted treatments for any of the crop species (data not shown), suggesting that plant water relations were also not likely a factor in compaction effects on growth.

\section{Discussion}

Secondary effects of soil compaction, such as poor drainage after rainfall events, reduced nutrient availability, and increased severity of insect pest pressure were important yield-determining factors for some crop species in some years of our field study. Cabbage and snap bean growth were most reduced by soil compaction in 1992 and 1994 (Table 1), when there were prolonged periods of saturated soil conditions after rainfall events in compacted plots. Gunjal et al. (1987) reported that adverse effects of soil compaction on yield of several field crops was exacerbated in wet years. The sensitivity of snap beans to flooding has been documented by Lakitan et al. (1992) who reported yield reductions of $50 \%$ or more after a 4-day flooding event under controlled greenhouse conditions. They also found that yield was more sensitive to flooding imposed during the reproductive stage compared to the early vegetative growth stage. This may explain why snap bean yield reductions in our field study (Table 1) were greater in 1994, when flooding occurred at 50 to 55 days after planting compared to 1992, when flooding occurred before flowering.

Sweet corn was the least sensitive to compaction of the four crops examined, as was also reported by Orzolek (1991). Sweet corn growth reductions due to compaction were nevertheless substantial in the first year of our study (1992), when fertilizer rates were relatively low and $\mathrm{N}$ deficiencies were observed (Tables 1 and 2). In contrast, in the second year, when fertilizer rates and leaf $\mathrm{N}$ levels were relatively high, sweet corn growth was only slightly affected by compaction. Voorhees (1990) attributed yield reductions in compacted field corn plots to lack of adequate N. Nutrient uptake is often constrained on compacted soils because of reduced root distribution (Hakansson et al, 1988), slowed root metabolism associated with hypoxia (Glinski and Liepic, 1990), or a reduction in the soil $\mathrm{N}$ pool because of increased activity of anaerobic denitrifying bacteria (Lowery and Schuler, 1991). Reduced oxygen availability in compacted soils also affects chemical and biological processes influencing $\mathrm{K}$ availability (Wolkowski, 1990). Leaf $\mathrm{K}$ levels were frequently lower in compacted plots in our field experiments (Table 2).

Slower seedling growth in compacted plots prolongs the period when plants are most susceptible to damage by some insect pests and competition from weeds. Such interactions have not been previously emphasized in the literature. In all 3 years, the slower growing cabbage seedlings in compacted plots suffered a more prolonged flea beetle infestation and greater leaf damage (20\% to $50 \%$ leaf area affected) than uncompacted plants. Flea beetle feeding became minimal by midseason, but the damage in early growth stages likely had a significant impact on yield. The use of cabbage transplants, which avoided the early seedling establishment phase when plants were most sensitive to flea beetle feeding, resulted in a smaller yield reduction on compacted soil than was observed in the direct-seeded cabbage (Table 1, 1993 data). It should be noted that compaction treatment also increased the labor required for adequate weed control for all crops. 
Table 4. Effect of soil compaction in the greenhouse experiment on $\mathrm{CO}_{2}$ assimilation rate $\left(\mathrm{A}_{\mathrm{co} 2}\right)$ and leaf nutrient status.

\begin{tabular}{|c|c|c|c|c|c|c|}
\hline \multirow[b]{2}{*}{ Crop } & \multirow[b]{2}{*}{ Treatment } & \multicolumn{2}{|c|}{$\underset{\left(\mu \mathrm{mol} \cdot \mathrm{m}^{-2} \mathrm{~s}^{-1}\right)}{\mathrm{A}_{\mathrm{CO} 2}}$} & \multicolumn{3}{|c|}{$\begin{array}{l}\text { Leaf tissue analyses } \\
\left(\mathrm{g} \cdot \mathrm{kg}^{-1}\right)\end{array}$} \\
\hline & & Lower leaf & Upper leaf & $\mathrm{N}$ & $P$ & $\mathrm{~K}$ \\
\hline \multirow[t]{2}{*}{$\overline{\text { Cabbage }}$} & Control & 21.9 & 20.7 & 0.471 & 0.058 & 0.351 \\
\hline & Compact & 19.9 & 20.8 & 0.443 & 0.050 & 0.312 \\
\hline \multirow[t]{2}{*}{ Cucumber } & Control & 21.0 & 17.7 & 0.522 & 0.041 & 0.151 \\
\hline & Compact & 19.3 & 17.0 & 0.531 & 0.039 & 0.184 \\
\hline \multirow[t]{2}{*}{ Snapbean } & Control & 15.6 & 13.7 & 0.490 & 0.032 & 0.295 \\
\hline & Compact & 16.6 & 14.7 & 0.504 & 0.041 & 0.363 \\
\hline \multirow[t]{2}{*}{ Sweetcorn } & Control & 28.1 & 30.1 & 0.392 & 0.026 & 0.338 \\
\hline & Compact & 26.5 & 26.3 & 0.402 & 0.026 & 0.332 \\
\hline \multicolumn{2}{|c|}{ Soil treatment (S) } & NS $(0.10)$ & NS & NS & NS & NS \\
\hline \multicolumn{2}{|c|}{ Crop (C) } & $* * *$ & $* * *$ & $* * *$ & $* * *$ & * \\
\hline \multicolumn{2}{|l|}{$\mathrm{S} \times \mathrm{C}$} & NS & NS $(0.18)$ & $*$ & $* *$ & * \\
\hline
\end{tabular}

NS, *, **, ***Nonsignificant or significant at $P<0.05,0.01$, and 0.001 , respectively.

An important objective of repeating the experiment under controlled greenhouse conditions was to compare species response to soil compaction per se (i.e., response to mechanical impedance), with secondary compaction effects minimized by careful management of soil water status, nutrient status, and weed and pest control. Measurements of soil and plant water potentials, leaf nutrient levels, and observations of pest pressure indicated that, at least relative to the field experiments, this objective was accomplished. Under these optimum greenhouse conditions, soil compaction did not have a significant effect on total biomass production of cucumber or sweet corn, but did significantly reduce total biomass of snap bean and cabbage (Table 3). The growth reductions of snap bean and cabbage could not be attributed to compaction effects on leaf turgor (data not shown), nutrient deficiency, or A,,, of individual leaves (Table 4), suggesting growth of these two species on compacted soil was more sink- than source-limited with regard to water, $\mathrm{N}$, and carbohydrate supply. Prior compaction and restricted root volume studies with sunflower (Andrade et al., 1993), wheat (Masle and Passioura, 1987; Masle and Farquhar, 1988), and beans (P. vulgaris, Carmi et al., 1983 ) reported that although shoot and root growth of compacted plants were stunted, A,, per unit leaf area was either unaffected or higher than in control plants. Andrade et al. (1993) found that higher A,, of plants grown on compacted soil was associated with a higher N per unit leaf area, and Masle and Farquhar (1988) measured higher ribulose 1,5-bisphosphate carboxylase activity in the leaves of compacted plants. These authors concluded that shoot growth was not limited by water, nutrients, or photosynthetic capacity. They suggested that growth of young plants on compacted soils is perhaps modulated by hormonal signals produced in roots when they come in contact with compacted soil layers.

Our results suggest considerable genotypic variation in the importance of any "root signal" control of shoot response to compaction. The lack of shoot growth reduction in cucumber and sweet corn grown on compacted soils under controlled conditions did not support a root signal hypothesis at these levels of compaction. The shoot growth reductions of cabbage and snap bean were consistent with the hypothesis, but root : shoot ratios were also reduced. This contrasts with sunflower (Andrade et al., 1993) and wheat (Masle and Passioura, 1987), where root : shoot ratio increased in response to compaction. The contrast between experiments in root : shoot ratio response to compaction may reflect fundamental genetic differences in partitioning response, or may be due to differences in soil types, environmental conditions, or sampling procedures used. Our greenhouse experiment was of relatively short duration and focused on early plant development. Partitioning response to compaction may vary with growth stage.

Root growth within the compacted soil layer was restricted for all crops in the greenhouse experiment, but sweet corn showed the smallest treatment effect on percent of roots at the 10 to $20 \mathrm{~cm}$ depth (compacted zone in compacted pots). This may provide a partial explanation for the lower sensitivity of this species to compaction. Taylor and Gardner (1960), using a wax substrate to create mechanical impedance, reported that corn seedlings developed more roots than cotton or pinto bean (P. vulgaris) seedlings within the wax substrate.

\section{Summary}

In the field, prolonged flooding after rainfall events, prolonged exposure to damaging insect pressure, and nutrient deficiencies in compacted plots often contributed to yield declines in the four crop species. Cabbage and snap bean were most sensitive to soil compaction, even under controlled greenhouse conditions where growth reductions could not be attributed to compaction effects on soil water status, leaf turgor, nutrient deficiency, or $A$,, of individual leaves. Cucumber response was more variable, but significant yield reductions associated with compaction treatments were observed in all 3 years of the field study. However, in the greenhouse experiment, no shoot growth reduction was observed in this species. Sweet corn showed almost no growth or yield reduction in one of the 3 years of the field study, when relatively high fertilizer rates were used, and total biomass production was not significantly affected by compaction treatment in the greenhouse experiment. Sweet corn showed the least restriction of root growth into the compacted soil layer.

A modulation of shoot growth response to compaction by hormonal signals from the roots was apparently not operative for cucumber or sweet corn within the context of our greenhouse experiment since these species exhibited no significant shoot growth reductions when grown on compacted soil. Shoot growth of cabbage and snap bean was reduced by compaction in the greenhouse experiment, consistent with a root signal hypothesis, but root growth and root : shoot ratio of these species were also reduced. Additional evaluation of these genotypic variations in growth response to soil compaction could he useful in crop selection and management of marginal land areas with compacted soils. 


\section{Literature Cited}

Allmaras, R.P., J.M. Kraft, and D.E. Miller. 1988. Effects of soil compaction and incorporated crop residues on root health. Annu. Rev. Phytopathology 26: 2 19-243.

Andrade, A., D.W. Wolfe, and E. Fereres. 1993. Leaf expansion, photosynthesis, and water relations of sunflower plants grown on compacted soil. Plant and Soil 149: 175-1 84.

Bremner, J.M. 196.5. Total nitrogen. In: C.A. Black (ed.). Methods of plant analysis. Part 2. Chemical and microbiological properties. Amer. Soc. of Agron., Madison Wis.

Brereton J.C., M. McGowan, and T.C.K. Dawkins. 1986. The relative sensitivity of spring barley, spring field beans, and sugar beet crops to soil compaction. Field Crops Res. 13:223-232.

Carmi, A., J.D. Hesketh, W.T. Enos, and J.B. Peters. 1983. Interrelationships between shoot growth and photosynthesis, as affected by root growth restriction. Photosynthetica 17:240-245.

Glinski, J. and J. Liepic. 1990. Soil physical conditions and plant roots. CRC Press, Boca Raton, Fla.

Gunjal, K., G. Lavoie, and G.S.V. Raghavan. 1987. Economics of soil compaction due to machinery traffic and implications for machinery selection. Can. J. Agr. Econ. 35:591-603.

Hakansson, I., W.B. Voorhees, and H. Riley. 1988. Vehicle and wheel factors influencing soil compaction and crop response in different traffic regimes. Soil Tillage Res. 11:239-282.

Hartung, W., J. Zhang, and W.J. Davies. 1994. Does abscisic acid play a stress physiological role in maize plants growing in heavily compacted soil? J. Expt. Bot. 45(271):221-226.

Henderson, C.W.L. 199 1. Sensitivity of eight cereal and legume species to the compaction status of deep, sandy soils. Austral. J. Expt. Agr. 31:347-355.

Kays S.J., C.W. Nicklow, and D.H. Simons. 1974. Ethylene in relation to the response of roots to physical impedance. Plant Soil 40:565-571.
Lakitan, B., D.W. Wolfe, and R.W. Zobel. 1992. Flooding affects snap bean yield and genotypic variation in leaf gas exchange and root growth response. J. Amer. Soc. Hort. Sci. 117:711-716.

Lachno D.R., R.S. Harrison-Murray, and L.J. Audus. 1982. The effects of mechanical impedance to growth on the levels of ABA and IAA in root tips of Zea mays L. J. Expt. Bot. 33:943-951.

Lemon, E.R. and C.L. Wiegand. 1962. Soil aeration and plant relations. II. Root respiration. Agron. J. 54:171-175.

Lowery, B. and R.T. Schuler. 1991. Temporal effects of subsoil compaction on soil strength and plant growth. Soil Sci. Soc. Amer. Proc. 55:216-223

Masle J. and G.D. Farquhar. 1988. Effects of soil strength on the relation of water-use efficiency and growth to carbon isotope discrimination in wheat seedlings. Plant Physiol. 86:32-38.

Masle J, and J.B. Passioura. 1987. The effect of soil strength on the growth of young wheat plants. Austral. J. Plant Physiol. 14: 643-656.

Orzolek, M.D. 1991. Establishment of vegetables in the field. HortTechnology 1:78-81.

Taylor, H.M. and H.R. Gardner. 1960. Use of wax substrates in root penetration studies. Soil Sci. Soc. Amer. Proc. 24:79-81.

Unger, P.W. and T.C. Kaspar. 1994. Soil compaction and root growth: A review. Agron. J. 86:759-766.

Van Es, H.M. and R.L. Hill. 1995. Soil compaction and structural degradation. In: R.L. Blevins (ed.). Crop residue and management manual for the northeast. Soil Water Conservation Soc., Ankeny, Iowa. (In press.)

Veen, B.W. 1982. The influence of mechanical impedance on the growth of maize roots. Plant Soil 66:101-109.

Voorhees, W.B. 1990. Yield effects of compaction-Are they significant? Amer. Soc. Agr. Eng. (St. Joseph, Mich.) paper no. 90-1076.

Wolkowski, R.P. 1990. Relationship between wheel traffic-induced soil compaction, nutrient availability, and crop growth: A review. J. Prod. Agr. 3:460-469. 